\title{
Studi Komparasi Taman Kota Lumintang Dan Taman Kota Puputan Margarana Niti Mandala Renon Sebagai Sarana Leisure And Recreation
}

Shindi Ayu Permatasari a, 1, I Gusti Agung Oka Mahagangga a, 2

${ }^{1}$ sindy.ayupermatasari@gmail.com, 2 okamahagangga@unud.ac.id

a Program Studi Sarjana Destinasi Pariwisata, Fakultas Pariwisata,Universitas Udayana, Jl. Dr. R. Goris, Denpasar, Bali 80232 Indonesia

\section{Abstract}

Lumintang City Park is located at Mulawarman Street, Lumintang, Dauh Puri Kaja, North Denpasar, while Renon City Park is located in Niti Mandala, Denpasar, Renon. Renon City Park Located in the middle of Denpasar City. Both places are in the same area, and not far from the city center. Both parks are very crowded visitors to do leisure and recreation activities. The method used to find the data is observation, interview, and questionnaire. The method used to determine the sample is quota sampling and accidental sampling. Methods for analyze data is comparative analysis and descriptive statistical analysis. The purpose of this research was to know the comparison between Lumintang city Park and Renon City Park as a place of leisure and recreation.

The result of comparison with the first aspect is he leisure equation as a activities and the mood / positive mental, the difference is in the number of visitors. the second is recreation equations visitors a lot to relax at the day, the difference is in the number of respondents. The third aspect is physical motivations the equaptions is for sports, the difference is the number of respondents. The fourth aspect is facilities include sports equipment and children playground, the equation good management, the difference is the number of respondents. The equation is a good parking area management and the differences is in the number of respondents and the equaptions is a good toilet management and the difference in the number of respondents. The similarity is there is no management for the trash can, the difference is in Lumintang city park many respondents said not good while in Renon city Park many respondents stated good. And the last management of the park bench the equation does not exist whereas the difference is in Lumintang city park many respondents stated good and in Renon City Park many respondents stated not good. The fifth aspect is visitor aspect of the equation there are many female visitors, the difference is number of respondents. The age aspect the equation is age of visitors is 16-25 years old, the difference is the number of respondents. Equality in employment is public servant, the difference is number of respondents. For the origin of the region there is no similarity and the difference is in Lumintang City Park many visitors that comes from Denpasar while in Renon City Park many visitors from the outside Denpasar.

\section{Keywords : comparison, leisure, recreation, lumintang city park, niti mandala renon city park}

\section{PENDAHULUAN}

Bali merupakan salah satu provinsi yang memiliki banyak sekali potensi dan kegiatan di sektor pariwisata yang sudah tidak diragukan lagi eksistensinya. sejumlah orang mengunjungi Bali untuk mengisi waktu luang mereka dengan cara berlibur, bersenang-senang menikmati keindahan alam yang ada di Bali. Tidak hanya wisatawan di luar Bali saja yang berlibur mengisi waktu luang mereka, masyarakat Kota Denpasar pun juga banyak yang mengisi waktu luang mereka. Kebanyakan masyarakat yang bertempat tinggal di kota memiliki sedikit waktu luang karena memiliki pekerjaan dan kegiatan yang padat, maka kebanyakan dari mereka memilih menghabiskan akhir pekan mereka dengan bersantai di taman-taman kota yang tidak jauh dari tempat tinggal mereka guna mengefisienkan waktu yang terbatas, jarak dan sekedar melepaskan penat. Salah satunya adalah Taman kota Lumintang dan
Taman Kota Puputan Margarana Niti Mandala Renon . Taman kota Lumintang terletak di jalan Mulawarman, Lumintang, Dauh Puri Kaja, Denpasar Utara. Taman Kota Lumintang ini memiliki fasilitas pendukung seperti jogging track, play ground mini, alat pembantu olahraga, adanya taman burung mini, penjual makanan yang cukup tertata, toilet, serta adanya atraksi air mancur yang dipertunjukan setiap hari sabtu dan minggu setiap pukul 19.00-21.00.

Taman Kota Puputan Margarana Niti Mandala Renon terletak di Niti Mandala, Denpasar, Renon.. Taman Kota Puputan Margarana Niti Mandala Renon ini memiliki area yang cukup luas dan memiliki banyak fasilitas pendukung seperti tempat jogging track, fasilitas alat bantu berolahraga, sarana taman bermain bagi anak anak, toilet, serta di sekeliling taman terdapat tanaman hijau yang rindang yang menambah keasrian Taman 
tersebut. Pada Taman Kota Puputan Margarana Niti Mandala Renon terdapat Monumen Bajra Shandi yang terletak di tengah-tengan Lapangan Renon. Monumen Perjuangan Rakyat Bali berisikan mengenai sejarah perjuangan Rakyat Bali melawan para penjajah, banyak masyarakat yang berkunjung pada Monumen Perjuangan Rakyat ini untuk berwisata dan secara tidak langsung mereka menghabiskan waktu luang mereka dengan cara berekreasi sembari memupuk Pengetahuan mengenai sejarah masyarakat Bali melawan penjajah.

Peneliti mengambil kedua lokasi ini untuk dibandingkan karena kedua tempat ini berada di lokasi yang tidak jauh dan berada di pusat kota, selain itu taman kota ini selalu ramai pengunjung. Banyak pengunjung yang melakukan kegiatan leisure and recreation di kedua taman kota tersebut. Adanya kedua taman ini sebagai sarana leisure and recreation penulis mengambil judul Studi Komparasi Taman Kota Lumintang Dan Taman Kota (Lapangan Puputan Margarana Niti Mandala) Renon Sebagai Sarana Leisure and Recreation. Berdasarkan latar belakang di atas maka rumusan masalah pada penelitian ini yaitu Bagaimana Komparasi fasilitas Taman Kota Lumintang dan Taman Kota Puputan Margarana Niti Mandala Renon sebagai sarana leisure and recreation. Tujuan penelitian ini dilakukan untuk mengetahui perbandingan Taman Kota Lumintang dan Taman Kota Puputan Margarana Niti Mandala Renon sebagai sarana leisure and recreation.

\section{TINJAUAN PUSTAKA}

\subsection{Telaah Hasil Penelitian Sebelumnya}

Penelitian pertama adalah skripsi yang diteliti oleh Miftahol Arifin (2006) dengan judul "Pemanfaatan Taman Bunga Kota, sebagai Aktivitas Leisure and Recreatio, diKabupaten Sumenep-Madura, Provinsi Jawa Timur"

Penelitian kedua adalah jurnal oleh Dinna Cahyaningrum (2013) dengan judul "Studi Komparasi Potensi Desa Wisata Wangunharja dan Wisata Sari Benihayu Dalam Satuan Kawasan Wisata Ciater di Kabupaten Subang".

\subsection{Landasan Konsep dan Teori Analisis}

Dalam artikel ini menggunakan beberapa konsep diantaranya konsep leisure (Torkildsen dalam Setiyani, 2012), konsep recreation (Merpaung, 2000 dalam Arifin 2006), konsep masyarakat lokal (Koentjaraningrat, 2009), konsep pengunjung (Rhesayana, 2014), konsep Motivasi (Pitana, 2005), konsep pengelolaan (Arikunto dalam Puji, 2016),dan konsep Public Space (Urban Land Institute dalam Prihutami, 2008).

\section{METODE PENELITIAN}

Lokasi penelitian ini adalah di Taman Kota Lumintang dan Taman Kota Niti Mandala Renon Denpasar Bali. Metode yang digunakan yaitu analisis statistik deskriptif Santoso (2014) . Jenis data yang digunakan adalah data kualitatif (Bungin, 2007) dan data kuantitatif (Kusmayadi dan Sugiarto, 2000). Sumber data yang digunakan yaitu data primer (Wardiyanta, 2006) mengenai sarana leisure dan recreation di Taman Kota Lumintang dan Taman Kota Puputan Margarana Niti Mandala Renon. Teknik pengumpulan data dilakukan dengan observasi (Black Dan Champion, 2001), wawancara (Setyadin, 2005:22) serta penyebaran kuesioner (Loraine, Christina, dan Malcolm, 2006) kepada 100 orang responden. Teknik penentuan sampel dalam penelitian ini adalah dengan quota sampling dimana dalam penyebarannya menggunakan metode accidental sampling. Teknik analisis data yang digunakan pada penelitian ini yaitu analisis komparasi menurut Sudjud dalam Ari Kunto (2006).

\section{IV.HASIL DAN PEMBAHASAN}

Taman Kota Lumintang adalah sebuah taman di Kota Denpasar Bali. Taman Kota ini memiliki luas sebesar $11.060 \mathrm{~m}^{2}$ dan dibangun pada tanggal 27 Februari 1999 yang bertepatan dengan hari jadi kota Denpasar. Walaupun Taman Kota Lumintang tidak memiliki lahan luas, namun taman ini memiliki fasilitas yang dapat dinikmati bagi pengunjung diantaranya menjadi keunikan adalah air mancur yang diiringi musik dan lampu warna-warni.

Sedangkan Taman Kota Niti Mandala Renon memiliki area cukup luas yakni 30.000 $\mathrm{m}^{2}$. Ciri khas dari taman kota ini adalah adanya monument Bajrasandi yang dibangun pada tahun 1981 namun pembangunannya terhenti tahun 1987. Kini monument tersebut sudah selesai dan masyarakat dapat memanfaatkannya untuk berbagai kepentingan. 


\subsection{Komparasi Taman Kota Lumintang dan}

Taman Kota Puputan Margarana Niti Mandala Renon

Komparasi Taman Kota Lumintang dan Taman Kota Puputan Margarana Niti Mandala Renon dilihat dari lima aspek yaitu leisure, recreation, motivasi fisik, sarana/fasilitas, dan pengunjung. Yang dapat dilihat sebagai berikut.

\subsubsection{Leisure}

Komparasi leisure di Taman Kota Lumintang dan Taman Kota Puputan Margarana Niti Mandala Renon dilihat dari aktivitas dan suasana hati/mental yang poitif dapat dilihat dari tabel 4.1 berikut:

Tabel 4.1

Komparasi Sarana Leisure di Taman Kota Lumintang dan Taman Kota Puputan Margarana Niti Mandala Renon

\begin{tabular}{|c|c|c|c|}
\hline No. & $\begin{array}{c}\text { Sarana } \\
\text { Leisure }\end{array}$ & $\begin{array}{c}\text { Taman } \\
\text { Kota } \\
\text { Lumintang }\end{array}$ & $\begin{array}{c}\text { Taman } \\
\text { Kota } \\
\text { Puputan } \\
\text { Margarana } \\
\text { Niti } \\
\text { Mandala } \\
\text { Renon }\end{array}$ \\
\hline 1. & Aktivitas & 29 & 18 \\
\hline 2. & $\begin{array}{c}\text { Suasana hati } \\
\text { atau mental } \\
\text { yang positif }\end{array}$ & 21 & 32 \\
\hline
\end{tabular}

Sumber : Data diolah dari penelitian 2017

Komparasi atau perbandingan di Taman Kota Lumintang dan Taman Kota Puputan Margarana Niti Mandala Renon bila dilihat dari persamaan sebagai sarana leisure yaitu bahwa dari 100 responden yang datang berkunjung pada kedua taman kota tersebut sama - sama melakukan leisure sebagai aktivitas dan suasan hati atau mental yang positif. Sedangkan perbedaan dari dua taman kota tersebut yaitu pengunjung yang melakukan leisure sebagi aktivitas di Taman Kota Lumintang lebih banyak yakni sebanyak 29 orang. Dan di Taman Kota Puputan Margarana Niti Mandala Renon hanya 18 orang. Sedangakan perbedaan yang dilihat dari leisure sebagai suasana hati atau mental yang positif di Taman Kota Lumintang sebanyak 21 orang dan di Taman Kota Puputan Margarana Niti Mandala Renon sebanyak 32 orang. Dari total keseluruhan pengunjung di Taman Kota Lumintang dan
Tama Kota Renon yang sebanyak 100 responden, banyak responden yang melakukan kegiatan leisure untuk memperbaiki suasana hati atau mental yang positif dengan banyak responden 53 orang.

\subsubsection{Recreation}

Komparasi Recreation di Taman Kota Lumintang dan Taman Kota Puputan Margarana Niti Mandala Renon dilihat dari pengunjung mengunjungi kedua taman sebagai santai sehari dan Tour sehari dapat dilihat dari tabel 4.2 .

Tabel 4.2

Komparasi Sarana Recreation di Taman Kota Lumintang dan Taman Kota Puputan Margarana Niti Mandala Renon

\begin{tabular}{|c|c|c|c|}
\hline No. & $\begin{array}{c}\text { Sarana } \\
\text { Recreation }\end{array}$ & $\begin{array}{c}\text { Taman } \\
\text { Kota } \\
\text { Lumintang }\end{array}$ & $\begin{array}{c}\text { Taman } \\
\text { Kota } \\
\text { Puputan } \\
\text { Margarana } \\
\text { Niti } \\
\text { Mandala } \\
\text { Renon }\end{array}$ \\
\hline 1. & $\begin{array}{c}\text { Santai } \\
\text { sehari }\end{array}$ & 46 & 41 \\
\hline 2. & $\begin{array}{c}\text { Tour } \\
\text { sehasi }\end{array}$ & 4 & 5 \\
\hline
\end{tabular}

Sumber : Data diolah dari penelitian 2017

Komparasi atau perbandingan yang ada di Taman Kota Lumintang dan Taman Kota Puputan Margarana Niti Mandala Renon jika dilihat dari persamaan sebagai sarana recreation yaitu bahwa dari 100 responden yang datang berkunjung pada kedua taman tersebut sama - sama melakukan recreation sebagai santai sehari dan tour sehari. Di Taman Lumintang sebanyak 50 orang dan pada Taman Kota Puputan Margarana Niti Mandala Renon sebanyak 50 orang Dari total keseluruhan pengunjung di Taman Kota Lumintang dan Taman Kota Puputan Margarana Niti Mandala Renon yakni sebanyak 100 responden dapat dilihat bahwa persamaannya berada pada banyaknya jumlah responden yang mengikuti kegiatan santai sehari yaitu sebnyak 87 orang dari 100 responden. Dan pada kedua taman tersebut perbedaannya terletak pada jumlah responden yang melakukan kegiatan recreation, yakni di Taman Kita Lumintang hanya sebanyak 4 orang dan di Taman Kota 
Puputan Margarana Niti Mandala Renon sebanyak 9 orang.

\subsubsection{Motivasi Fisik}

Komparasi motivasi di Taman Kota Lumintang dan Taman Kota Puputan Margarana Niti Mandala Renon dilihat dari motivasi pengunjung mengunjungi kedua taman untuk bersantai,berolahraga,piknik dapat dilihat dari tabel 4.3

Tabel 4.3

Komparasi Motivasi Fisik Pengunjung di Taman Kota Lumintan dan Taman Kota Puputan Margarana Niti Mandala Renon

\begin{tabular}{|c|c|c|c|}
\hline No. & $\begin{array}{c}\text { Motivasi } \\
\text { Fisik }\end{array}$ & $\begin{array}{c}\text { Taman } \\
\text { Kota } \\
\text { Lumintang }\end{array}$ & $\begin{array}{c}\text { Taman Kota } \\
\text { Puputan } \\
\text { Margarana } \\
\text { Niti Mandala } \\
\text { Renon }\end{array}$ \\
\hline 1. & Bersantai & 13 & 10 \\
\hline 2. & Olahraga & 33 & 35 \\
\hline 3. & Piknik & 4 & 5 \\
\hline
\end{tabular}

Sumber : Data diolah dari penelitian 2017

Komparasi atau perbandingan yang ada di Taman Kota Lumintang dan Taman Kota Puputan Margarana Niti Mandala Renon jika dilihat dari persamaan sebagai motivasi fisik yaitu bahwa banyak responden yang melakukan kegiatan olahraga dengan banyak responden 68 orang dan kemudian yang kedua paling banyak yaitu responden untuk bersantai sebanyak 23 orang dan motivasi fisik yang terakhirr adalah melakukan kegiatan piknik dengan jumlah responden 9 orang dari total kedua responden. Sedangkan perbedaan pada kedua taman tersebut yakni terletak pada jumlah responden yang melakukan motivasi fisik. Pengunjung di Taman Kota Lumintang yang berolahraga sebanyak 33 orang dan di Taman Kota Puputan Margarana Niti Mandala Renon sebanyak 35 orang. Pengunjung yang melakukan kegiatan bersantai di Taman Kota Lumintang sebanyak 13 orang dan di Tamn Kota Renon sebanyak 10 orang, sedangkan pengunjung yang melakukan kegiatan piknik di Taman Kota Lumintang sebanyak 4 orang dan di Taman Kota Puputan Margarana Niti Mandala Renon sebanyak 5 orang.

\subsubsection{Sarana /Fasilitas}

Komparasi Recreation di Taman Kota Lumintang dan Taman Kota Puputan Margarana Niti Mandala Renon dilihat dari sarana/fasilitas alat olahraga dan tempat bermain anak, area parkir, toilet, tempat sampah, dan bangku taman dikelola dengan baik atau kurang baik di kedua taman dapat dilihat dari tabel berikut:

Tabel 4.4

Komparasi Pengelolaan Alat Olahraga dan Tempat Bermain Anak di Taman Kota Lumintang dan Taman Kota Puputan Margarana Niti Mandala Renon

\begin{tabular}{|c|l|c|c|}
\hline No. & \multicolumn{1}{|c|}{ Taman Kota } & Ya & Tidak \\
\hline 1. & $\begin{array}{l}\text { Taman Kota } \\
\text { Lumintang }\end{array}$ & 48 & 2 \\
\hline 2. & $\begin{array}{l}\text { Taman Kota Puputan } \\
\text { Margarana Niti } \\
\text { Mandala Renon }\end{array}$ & 43 & 7 \\
\hline
\end{tabular}

Sumber : Data diolah dari penelitian 2017

Komparasi atau perbandingan pada Taman Kota Lumintang dan Taman Kota Puputan Margarana Niti Mandala Renon jika dilihat dari persamaan dari segi pengelolaan sarana atau fasilitas terkait alat olah raga tempat bermain anak. Dari 50 responden baik pada Taman Kota Lumintang dan Taman Kota Puputan Margarana Niti Mandala Renon yang mengatakan "ya" atau alat olahraga dan tempat bermain menunjang aktifitas pengunjung sebanyak 48 orang dan 43 orang. Sehingga dapat disimpulkan bahwa persamaannya yaitu pengelolaan sarana atau fasilitas pada kedua taman kota sama - sama menunjuang kegiatan leisure and recreation. Perbedaannya terletak pada jumlah setiap responden pada masing-masing taman yang mengatakan bahwa fasilitas penunjang alat olahraga dan tempat bermain anak kurang menunjang kegiatan leisure and recreation yaitu Taman Kota Lumintang sebanyak 2 orang dan pada Taman Kota Puputan Margarana Niti Mandala Renon sebanyak 7 orang. 
Tabel 4.5

Komparasi Pengelolaan Area Parkir Di Taman Kota Lumintang Dan Taman Kota Puputan Margarana Niti Mandala Renon

\begin{tabular}{|c|l|c|c|}
\hline No. & \multicolumn{1}{|c|}{ Taman Kota } & Ya & Tidak \\
\hline 1. & $\begin{array}{l}\text { Taman Kota } \\
\text { Lumintang }\end{array}$ & 40 & 10 \\
\hline 2. & $\begin{array}{l}\text { Taman Kota } \\
\text { Puputan Margarana } \\
\text { Niti Mandala Renon }\end{array}$ & 35 & 15 \\
\hline
\end{tabular}

Sumber : Data diolah dari penelitian 2017

Komparasi atau perbandingan terhadap sarana atau fasilitas terkait dengan area parkir di Taman Kota Lumintang dan Taman Kota Puputan Margarana Niti Mandala Renon yaitu persamaannya terletak pada banyak responden yang mengatakan pengelolaan terhadap area parkir baik atau "ya" dengan banyak responden yaitu 40 responden dan 35 responden atau jumlah totalnya sebanyak 75 responden. Sedangkan perbedaan dari kedua taman tersebut terletak pada responden yang mengatakan "tidak" atau pengelolaan terhadap area parkir kurang baik dengan jumlah 10 responden dan 15 responden. Hal ini dikarenakan penataan parkir kurang tertata, area parkir banyak memakan area jalan, banyak petugas parkir, keamanan area parkir kurang terjamin dikarenakan ada salah satu responden yang mengaku kehilangan helm, dan dalam penarikan uang karcis petugas sering lupa sehingga pengunjung diminta membayar lagi.

Tabel 4.6

Komparasi Pengelolaan Toilet Di Taman Kota Lumintang Dan Taman Kota Puputan Margarana Niti Mandala Renon

\begin{tabular}{|c|l|c|c|}
\hline No. & \multicolumn{1}{|c|}{ Taman Kota } & Ya & Tidak \\
\hline 1. & $\begin{array}{l}\text { Taman Kota } \\
\text { Lumintang }\end{array}$ & 29 & 21 \\
\hline 2. & $\begin{array}{l}\text { Taman Kota Puputan } \\
\text { Margarana Niti } \\
\text { Mandala Renon }\end{array}$ & 30 & 20 \\
\hline
\end{tabular}

Sumber : Data diolah dari penelitian 2017

Komparasi atau perbandingan di Taman Kota Lumintang dan Taman Kota Puputan Margarana Niti Mandala Renon berdasarkan sarana atau fasilitas toilet yaitu persamaannya terletak pada banyak responden mengatakan "ya" atau pengelolaan fasilitas toilet baik dengan responden sebanyak 29 orang dan 30 orang, atau totalnya berjumlah 59 responden. Dan perbedaaan dari kedua taman kota ini terletak pada banyaknya responden yang menyataakan tidak atau pengelolaan fasilitas toilet kurang baik dengan alasan tulisan toilet kurang besar sehingga menyebabkan pengunjung tidak mengetahui lokasi toilet, toilet kurang bersih, kurangnya toilet di setiap taman kota.

Tabel 4.7

Komparasi Pengelolaan Tempat Sampah di Taman Kota Lumintang dan Taman Kota Puputan Margarana Niti Mandala Renon

\begin{tabular}{|c|l|c|c|}
\hline No. & \multicolumn{1}{|c|}{ Taman Kota } & Ya & Tidak \\
\hline 1. & $\begin{array}{l}\text { Taman Kota } \\
\text { Lumintang }\end{array}$ & 21 & 29 \\
\hline 2. & $\begin{array}{l}\text { Taman Kota Puputan } \\
\text { Margarana Niti } \\
\text { Mandala Renon }\end{array}$ & 47 & 3 \\
\hline
\end{tabular}

Sumber : Data diolah dari penelitian 2017

Komparasi atau perbandingan dari Taman Kota Lumintang dan Taman Kota Puputan Margarana Niti Mandala Renon bila dilihat dari segi fasilitas tempat sampah yaitu persamaannya tidak ada dikarenakan jumlah pengunjung terbanyak yang mengunjungi Taman Kota Puputan Margarana Niti Mandala Renon sebanyak 47 responden mengatakan "ya" pengelolaan tempat sampah yang ada dikelola dengan baik sedangkan jumlah pengunjung terbanyak dari Taman Kota Lumintang sebanyak 29 responden menyatakan "tidak" pada pengelolaan tempat sampah dengan alasan kurang merata disetiap sudut, banyak tempat sampah yang rusak, terkadang tempat sampah tegeletak atau jatuh dan membuat sampah berserakan, dan lebih di perbanyak lagi peletakan tempat sampah yang ada.

Tabel 4.8

Komparasi Pengelolaan Bangku Taman di

Taman Kota Lumintang dan Taman Kota Puputan Margarana Niti Mandala Renon

\begin{tabular}{|c|l|c|c|}
\hline No. & \multicolumn{1}{|c|}{ Taman Kota } & Ya & Tidak \\
\hline 1. & $\begin{array}{l}\text { Taman Kota } \\
\text { Lumintang }\end{array}$ & 30 & 20 \\
\hline 2. & $\begin{array}{l}\text { Taman Kota Puputan } \\
\text { Margarana Niti } \\
\text { Mandala Renon }\end{array}$ & 9 & 41 \\
\hline
\end{tabular}

Sumber : Data diolah dari penelitian 2017 
Komparasi atau perbandingan dari Taman Kota Lumintang dan Taman Kota Puputan Margarana Niti Mandala Renon bila dilihat dari pengelolaan bangku taman yaitu persamaannya tidak ada dikarenakan jumlah pengunjung terbanyak yang mengunjungi Taman Kota Lumintang sebanyak 30 responden mengatakan "ya" sarana bangku taman di kelola dengan baik dan jumlah pengunjung terbanyak dari Taman Kota Puputan Margarana Niti Mandala Renon sebanyak 41 responden mengatakan "tidak" sarana bangku taman kurang baik pengeloaannya dengan alasan penataan bangku taman kurang merata, fasilitas bangku taman terlalu sedikit untuk taman seluas Taman Kota Puputan Margarana Niti Mandala Renon, bangku taman banyak dipakai untuk menaruh tas.

\subsubsection{Pengunjung}

Komparasi pengunjung yang mengunjungi di Taman Kota Lumintang dan Taman Kota Puputan Margarana Niti Mandala Renon dilihat dari jenis kelamin pengunjung mengunjungi kedua taman sebagai leisure and recreation dapat dilihat dari tabel 4.9.

Tabel 4.9

Komparasi Pengunjung Berdasarkan Jenis Kelamin di Taman Kota Lumintang dan Taman Kota Puputan Margarana Niti Mandala Renon

\begin{tabular}{|c|l|c|c|}
\hline No. & Taman Kota & Laki-laki & Perempuan \\
\hline 1. & $\begin{array}{l}\text { Taman Kota } \\
\text { Lumintang }\end{array}$ & 19 & 31 \\
\hline 2. & $\begin{array}{l}\text { Taman Kota } \\
\text { Puputan } \\
\text { Margarana } \\
\text { Niti Mandala } \\
\text { Renon }\end{array}$ & 17 & 33 \\
\hline
\end{tabular}

Sumber: Data diolah dari penelitian 2017

Komparasi atau perbandingan di Taman Kota Lumintang dan Taman Kota Puputan Margarana Niti Mandala Renon jika dilihat dari segi jenis kelamin persamaannya terletak pada banyak pengunjung yang datang yaitu berjenis kelamin perempuan dengan jumlah masing - masing yaitu 31 orang dan 33 orang atau totalnya sebanyak 64 orang. Dan perbedaannya terletak pada jumlah pengunjung yang berjenis kelamin laki - laki dengan jumlah masing - masing 19 orang dan 17 orang.
Tabel 4.10

Komparasi Pengunjung Berdasarkan Umur Di Taman Kota Lumintang Dan Taman Kota Puputan Margarana Niti Mandala Renon

\begin{tabular}{|c|c|c|c|c|c|c|}
\hline No & Taman Kota & $>15$ & $\begin{array}{c}16- \\
25\end{array}$ & $\begin{array}{c}26- \\
35\end{array}$ & $\begin{array}{c}36- \\
45\end{array}$ & $>45$ \\
\hline 1. & $\begin{array}{c}\text { Taman Kota } \\
\text { Lumintang }\end{array}$ & 3 & 20 & 14 & 6 & 7 \\
\hline & $\begin{array}{c}\text { Taman Kota } \\
\text { Puputan } \\
\text { Margarana } \\
\text { Niti } \\
\text { Mandala } \\
\text { Renon }\end{array}$ & 2 & 32 & 6 & 6 & 4 \\
\hline
\end{tabular}

Sumber : Data diolah dari penelitian 2017

Komparasi atau perbandingan pada Taman Kota Lumintang dan Taman Kota Puputan Margarana Niti Mandala Renon berdasarkan umur dapat dilihat dari persamaannya yang terletak pada banyak responden yang umurnya 16 - 25 tahun dengan jumlah total 52 responden dari jumlah keseluruhan responden. Selain itu persamaannya lagi terletak pada responden dengan umur 36 - 45 yahun dengan banyak 6 responden. Sedangkan perbedaaanya terletak pada responden yang umurnya $>45$ tahun dengan banyak 7 dan 4 responden. Selain itu juga terletak pada respondenyang berumur $<15$ tahun dengan banyak responden yaitu 3 dan 2 responden.

Tabel 4.11

Komparasi Pengunjung

Berdasarkan Asal Daerah di Taman

Kota Lumintang dan Taman Kota

Puputan Margarana Niti Mandala Renon

\begin{tabular}{|c|l|c|c|}
\hline No. & Taman Kota & Denpasar & $\begin{array}{c}\text { Luar } \\
\text { Denpasar }\end{array}$ \\
\hline 1. & $\begin{array}{l}\text { Taman Kota } \\
\text { Lumintang }\end{array}$ & 31 & 19 \\
\hline 2. & $\begin{array}{l}\text { Taman Kota } \\
\text { Puputan } \\
\text { Margarana } \\
\text { Niti } \\
\text { Mandala } \\
\text { Renon }\end{array}$ & 17 & 33 \\
\hline
\end{tabular}

Sumber : Data diolah dari penelitian 2017

Komparasi atau perbandingan dari Taman Kota Lumintang dan Taman Kota Puputan Margarana Niti Mandala Renon bila dilihat dari segi asal responden yaitu persamaannya tidak ada dikarenakan jumlah 
pengunjung terbanyak yang mengunjungi Taman Kota Lumintang sebanyak 31 responden dari Denpasar dan jumlah pengunjung terbanyak dari Taman Kota Puputan Margarana Niti Mandala Renon sebanyak 33 responden dari luar Denpasar.

Tabel 4.36

Komparasi Pengunjung Berdasarkan Jenis Pekerjaan di Taman Kota Lumintang dan Taman Kota Puputan Margarana Niti Mandala Renon

\begin{tabular}{|c|l|c|c|}
\hline No. & $\begin{array}{c}\text { Taman } \\
\text { Kota }\end{array}$ & $\begin{array}{c}\text { Taman } \\
\text { Kota } \\
\text { Lumintang }\end{array}$ & $\begin{array}{c}\text { Taman } \\
\text { Kota } \\
\text { Puputan } \\
\text { Margarana } \\
\text { Niti } \\
\text { Mandala } \\
\text { Renon }\end{array}$ \\
\hline 1. & $\begin{array}{l}\text { Pelajar/ } \\
\text { mahasiswa }\end{array}$ & 3 & 2 \\
\hline 2. & PNS & 20 & 32 \\
\hline 3. & Wiraswasta & 14 & 6 \\
\hline 4. & $\begin{array}{l}\text { Ibu Rumah } \\
\text { Tangga }\end{array}$ & 6 & 6 \\
\hline 5. & Lain-lain & 7 & 4 \\
\hline
\end{tabular}

Sumber : Data diolah dari penelitian 2017

Komparasi atau perbandingan baik Taman Kota Lumintang dan Taman Kota Puputan Margarana Niti Mandala Renon bila dilihat dari segi jenis pekerjaan yaitu persamaannya terletak pada banyak responden yang mengunjungi Taman Kota Lumintang ataupun Taman Kota Puputan Margarana Niti Mandala Renon yaitu responden yang masih pelajar atau mahasiswa dengan banyak total responden 45 responden dari total. Dan perbedaannya terletak pada jumlah responden yang bekerja sebagai pegawai negeri karena di Taman Kota Lumintang yang berprofesi sebagai pegawai negeri sebanyak 4 responden dan untuk di Taman Kota Puputan Margarana Niti Mandala Renon tidak ada responden yang bekerja sebagai pegawai negeri. Dan untuk profesi ibu rumah tangga juga ada perbedaan di kedua taman kota yaitu dengan jumlah masing masing 10 responden dan 7 responden. Sedangkan pada jenis pekerjaan lain - lain juga ada perbedaan yaitu di Taman Kota Lumintang 11 responden bekerja sebagai POLRI, perawat, swasata, dan vidio editor. Dan di Taman Kota Puputan Margarana Niti
Mandala Renon sebanyak 3 responden bekerja sebagai swasta.

\section{PENUTUP}

\subsection{Simpulan}

Taman Kota Lumintang berada di Denpasar Timur, sedangkan Taman Kota Puputan Margarana Niti Mandala Renon terletak di tengah - tengah Kota Denpasar. pada Taman Kota Lumintang ini pengunjung melakukan Leisure and Recreation sebagai aktivitas dan santai sehari, kemudian sebagian besar berasal dari Denpasar dengan karakteristik umur antara 16-25 tahun, dan pekerjaan sebagaian besar pegawai negeri, serta berdasarkan jenis kelamin yang mengunjungi Taman Kota Lumintang adalah Perempuan.Pada Taman Kota Puputan Margarana Niti Mandala Renon ini pengunjung melakukan Leisure and Recreation sebagai suasana hati atau mental yang positif dan santai sehari, serta sebagian besar berasal dari luar Denpasar dengan karakteristik umur antara 1625 tahun dengan pekerjaan sebagaian besar pelajar atau mahasiswa serta lebih banyak berjenis kelamin perempuan.

Komparasi Taman Kota Lumintang dan Taman Kota Puputan Margarana Niti Mandala Renon berdasarkan dari segi aspek fasilitas yaitu dilihat dari persamaan pada kedua taman tersebut yakni sama - sama memiliki fasilitas toilet yang memadai sedangkan dilihat dari perbedaannya dapat dilihat dari segi fasilitas alat olahraga dan tempat bermain anak, tempat parkir, dan bangku taman pada Taman Lumintang lebih memadai bila dibandingkan dengan Taman Kota Puputan Margarana Niti Mandala Renon karena di Taman Kota Puputan Margarana Niti Mandala Renon masih belum memadai. Serta dilihat dari segi tempat sampah, pada Taman Kota Lumintang belum memadai dan pada Taman Kota Puputan Margarana Niti Mandala Renon lebih memadai. Sehingga dapat diketahui makna persamaan pada kedua taman tersebut yaitu sama-sama memiliki fasilitas yang menunjang sebagai tempat pemanfaatan leisure and recreation. Dan makna perbedaannya yaitu fasilitas di Taman Kota Lumintang lebih baik dan sebagian besar lebih memadai sedangkan di Taman Kota Puputan Margarana Niti Mandala Renon fasilitas yang tersedia belum sepenuhnya memadai. 


\subsection{Saran}

Sarana atau fasilitas di Taman Kota Puputan Margarana Niti Mandala Renon bisa di tambah untuk bangku taman diperbanyak jumlah dan peletakannya lebih dimeratakan, dibuatkan area khusus untuk tempat parkir. Tulisan papan toilet lebih di perbesar agar orang-orang yang berkunjung mengetahui dimana letak toilet tersebut dan untuk Kota Lumintang penambahan fasilitas tempat sampah dan tempat sampah yang sudah rusak diganti dengan yang lebih baik, kemudian fasilitas toilet di tambah.

Bagi pengunjung yang datang ke Taman Kota Lumintang dan Taman Kota Puputan Margarana Niti Mandala Renon diharapkan tetap menjaga fasilitas yang sudah tersedia, menjaga kebersihan agar Taman Kota Lumintang dan Taman Kota Puputan Margarana Niti Mandala Renon tetap dapat dijasikan sebagai sarana leisure dan recreation.

\section{DAFTAR PUSTAKA}

.Undang-Undang Repuplik Indonesia No. 10 Tahun 2009 tentamg Kepariwisataan.

Ardiansyah, Fikry. 2014. Analisis Karakteristik Dan Persepsi Pengguna Taman Kota Dalam Upaya Meningkatkan Fungsi Taman Kota Sebagai Sarana Rekreasi Masyarakat Di Kota Bandung. Skripsi. Fakultas Pendidikan Ilmu Sosial Universitas Pendidikan Indonesia.

Arifin, Miftahol. 2006. Pemanfaatan Taman Bunga Kota, sebagai Aktivitas Leisure and Recreation. Laporan Akhir. Denpasar:Fakultas Pariwisata Universitas Udayana.

Arikunto, Suharsimi. 2014. Prosedur Penelitian Suatu Pendekatan Praktik. Jakarta: PT Rineka Cipta.

Black, James dan Dean Champion. 2001. Metode dan Masalah Penelitian Sosial. Bandung: PT Refika Aditama.

Blaxter, Hughes, dan Tight. 2006. How To Reaserch. Indonesia: PT Indeks Kelompok Gramedia.

Bungin, Burhan. 2007. Penelitian Kualitatif: Komunikasi, Ekonomi, Kebijakan Publik, Dan Ilmu Sosial Lainnya. Jakarta: Prenada Media Group.

Koentjaraningrat. 2005. Pengantar Antropologi - Jilid I. Jakarta: PT Asdi Mahasatya.

Kusmayadi, dan Endar Sugiarti. 2000. Metodologi Penelitian Dalam Bidang Kepariwisataan. Jakarta: Gramedia Pustaka.

Madjid, Karina Aprilia, dan Ida Ayu Suryasih. 2015. "Pemanfaatan Pantai Perancak Sebagai Lokasi Aktivitas Leisure And Recreation Di Desa Tibubeneng". Jurnal Destinasi Pariwisata Vol.3 No.2

Puji, Purwani. 2016. Pengelolaan Perpustakaan Sekolah Di Smk Ma'arif 2 Gombong. S1 Thesis, Universitas Negeri Yogyakarta.
Santoso, Singgih. 2014. Panduan Lengkap SPSS Versi 20 Edisi Revisi. Jakarta: PT.Elex Media Komputindo.

Setiyani, Ari. 2012. Mengisi Waktu Luang Pada Siswa SMA Negeri 1 Perancak. Skripsi. Fakultas Ilmu Pendidikan Yogyakarta

Setyadin. 2005. Metode Penelitian Kualitatif: Teori dan Praktik. Jakarta: Bumi Aksara.

Sugiono. 20113. Metodologi Penelitian Manajemen. Yogyakarta: Alfabata Bandung.

Wardiyanta. 2006. Metode Penelitian Pariwisata: Edisi Pertama. Yogyakarta: Andy Yogyakarta. 